\title{
Paroxysmal non-kinesigenic dyskinesia
}

INSERM

\section{Source}

INSERM. (1999). Orphanet: an online rare disease and orphan drug data base.

Paroxysmal non-kinesigenic dyskinesia. ORPHA:98810

Paroxysmal non-kinesigenic dyskinesia (PNKD) is a form of paroxysmal dyskinesia (see this term), characterized by attacks of dystonic or choreathetotic movements precipitated by stress, fatigue, coffee or alcohol intake or menstruation. 